\title{
Penetration of Monrovia Surgeonfish Acanthurus monroviae (Perciformes: Acanthuridae) to the Black Sea
}

\author{
Alexander Boltachev ${ }^{1, *}\left(\mathbb{D}\right.$, Evgeniia Karpova ${ }^{1, *}$ (I) \\ ${ }^{1}$ Institute of Marine Biological Research of RAS, 2, Nakhimov ave., 299011, Russian Federation
}

\author{
Article History \\ Received 23 November 2018 \\ Accepted 28 April 2020 \\ First Online 05 May 2020

\section{Corresponding Author \\ Tel.: +79787187890 \\ E-mail:a_boltachev@mail.ru karpova_jey@mail.ru}

\begin{abstract}
The Monrovia Surgeonfish Acanthurus monroviae Steindachner, 1876 is reported for the first time in the Black Sea off the southwestern coast of Crimea $\left(44^{\circ} 29.5^{\prime} \mathrm{N}\right.$; $33^{\circ} 35.5^{\prime} \mathrm{E}$ ). The single specimen was caught by the commercial trap net on September 19, 2018; its standard length was $195 \mathrm{~mm}$. The most realistic version of its occurrence is the self-penetration of this specimen into the Black Sea from the Mediterranean Sea. Over the past 20 years, twelve fish species that had not previously been met in the Black Sea were registered near the southwestern coast of Crimea.
\end{abstract}

\section{Keywords}

Alien species

Introduction

Black Sea

Acanthuridae

\section{Introduction}

Among 86 valid species of the Acanthuridae family, only four ones have been registered in the East Atlantic (Fricke, Eschmeyer \& Van der Laan, 2019), of which the most common and widespread species is the Monrovia Surgeonfish Acanthurus monroviae Steindachner, 1876. Although fishes of this family are widespread in tropical and subtropical waters of the Indian, Pacific and Atlantic oceans, they did not inhabit the seas of the Mediterranean basin until recently (Nelson, 2006). By now, six species of the Acanthuridae family have been registered in the Mediterranean Sea (Evans, Tonna \& Schembri, 2017). The first specimen of $A$. monroviae in the Alboran Sea off the coast of Spain in the Marbella area about $70 \mathrm{~km}$ from the Strait of Gibraltar was encountered in 1981 (Crespo, Rey \& Garcia, 1987). Only 13 years later, another specimen of $A$. monroviae was caught, that time near the eastern coast of the Mediterranean Sea near Haifa (Israel), more than 3,700 km away from the Atlantic Ocean (Golani, Sonin, 1996).

The native habitat of this species extends along the coast of West Africa from Morocco to Angola, including Cape Verde, the Canary Islands, and São Tomé and Príncipe in the Gulf of Guinea (Fischer, Bianci \& Scott, 1981; Fricke et al., 2019). In June 2002, the Monrovia Surgeonfish was found off the coast of Brazil in the Laje de Santos Marine State Park (24 $15^{\prime} \mathrm{S} ; 46^{\circ} 10^{\prime} \mathrm{W}$ ) and in December 2007 near the coast of Portugal $\left(38^{\circ} 43^{\prime} \mathrm{N}\right.$; $9^{\circ} 07^{\prime} \mathrm{W}$ ) (Luiz-Junior, Floeter, Gasparini, Ferreira \& Wirtz, 2004; Costa, Gonçalves, 2013). Later, the species was discovered off the coast of southern Portugal (Vasconcelos, Carvalho, Moura, Ramos \& Gaspar, 2018). The significant increase in the frequency of occurrence and expansion of the range of $A$. monroviae in the Mediterranean Sea has been observed since the 
beginning of the 2000-s. Several single specimens were encountered near the northern coast of Africa - Algeria and Tunisia, - and in 2015 one specimen was hunted by a spearfishing man near the coast of Salamis Island in the southwestern part of the Aegean Sea (Batjakas, Kampouris \& Papadas, 2015; Langeneck et al., 2015; Vasconcelos, Carvalho, Moura, Ramos \& Gaspar, 2018). However, most of registrations (12) of the Monrovia Surgeonfish were made near the island of Malta in the period from 2013 to 2016, where this species was either visually observed or hunted by spearfishing hunters, with several specimens at once being registered in one case (Darmanin, Vella \& Vella, 2016; Evans et al., 2017).

This study aims to document the first finding of this alien species in the Black Sea off the coast of Crimea, as well as to present the morphological description of the caught specimen, adaptive analysis of the species, and probable vectors of its penetration.

\section{Materials and Methods}

A specimen of $A$. monroviae was found on September 19, 2018 in the catch of the commercial trap net set $250 \mathrm{~m}$ west off the entrance to Balaklava Bay in the southwestern part of the Crimean Peninsula $\left(44^{\circ} 29.5^{\prime} \mathrm{N} ; 33^{\circ} 35.5^{\prime} \mathrm{E}\right)$ (Figure 1 ), and it was given alive by fishermen to the authors of this article. This is the first finding of a representative of the Acanthuridae family in the Black Sea. The commercial trap net was set in the coastal zone at a depth of $15-20 \mathrm{~m}$. The surface water temperature was $23^{\circ} \mathrm{C}$, and the salinity was $18 \%$. Currently, this specimen is exhibited in the Sevastopol Aquarium-Museum. The morphometric analysis is performed using photographic images of the specimen.

\section{Results}

The total length of the specimen under study is 235 $\mathrm{mm}$, and the standard length is $195 \mathrm{~mm}$. The morphometric characteristics of the specimen are given in Table 1.

Dorsal fin with 9 spines and 25 soft rays; anal fin with 3 spines and 25 soft rays; pectoral fin with 16 soft rays; ventral fin with 1 spine and 5 soft rays. Caudal fin of semilunar shape, with elongated marginal rays. Mouth small and terminal; teeth flat and clearly visible. Body deep and noticeably compressed laterally. Eye iris red-brown. Dorsal fin long, with small poisonous spiny rays in its front, begins a little behind the vertical through the posterior edge of the eye orbit. All fins complexly colored in shades of brown, green, yellow and blue, with blue stripes on dorsal, anal and pectoral fins; distal edge of pectoral fin of yellowish color (Figure 2a).

After being caught and in the first days of keeping in the aquarium, the specimen had light brown color of the head and body with the slightly darker dorsal part with numerous longitudinal curved thin blue lines (Figure 2b). A few days later, the fish body turned light blue due to the fact that the blue lines became much wider, with narrow brown strips interspersing them. However, in stressful situations it turned brown again in a few seconds. On the caudal peduncle of this species there is a large bright yellow spot with a large lanceolate poisonous spike in its central part.

On the second day after being placed in the quarantine aquarium, the fish began to actively feed on shredded shrimp and benthic algae that covered stones in the aquarium. After the 12-days adaptation from the Black-Sea water salinity (18\%) to the oceanic one (35 $\%$ ), the specimen was settled in a demonstration aquarium.

\section{Discussion}

A. monroviae is a relatively eurybiontic species. This is a demersal fish; it lives in the depths from 2 to $200 \mathrm{~m}$, usually from 5 to $40 \mathrm{~m}$ over hard ground - rocks and corals, and occurs also in lagoons and estuarine

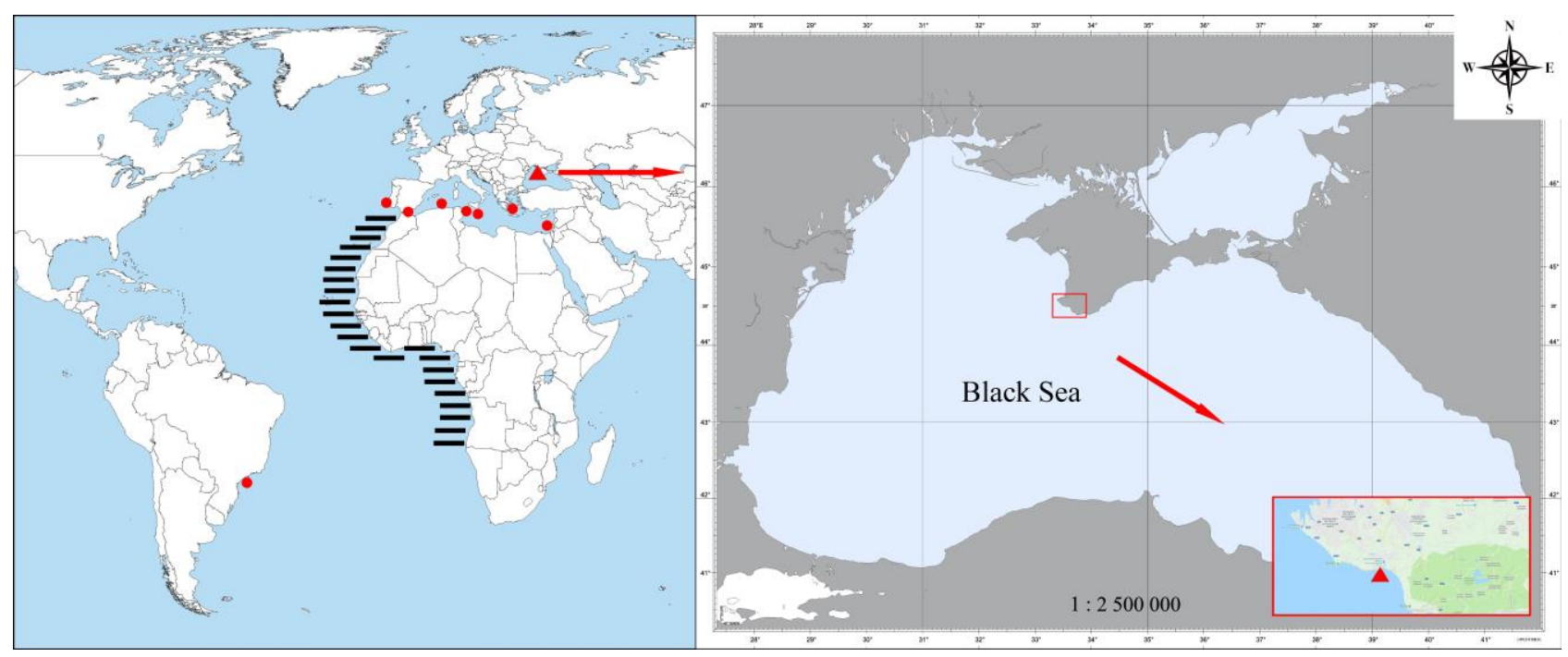

Figure 1. Area of finding Acanthurus monroviae; hatching - native area, round markers - sites of finding, triangular marker - the last find in the Black Sea. 
zones of rivers. It is a thermophilic species and it prefers water temperature $20-25^{\circ} \mathrm{C}$ (Fischer et al., 1981; Golani et al., 2013). The eggs and larvae of $A$. monroviae are pelagic. Its main food is benthic algae and, to a lesser extent, detritus, small bottom-dwelling invertebrates, phyto- and zooplankton. On the whole, the biology of this species has been insufficiently studied (Golani et al., 2013; Batjakas et al., 2015). A. monroviae can demonstrate the social behavior in shoaling (Luiz-Junior et al., 2004). Within the native range, it has limited commercial value and is consumed by local people (Fischer et al., 1981).

Due to its beautiful coloring, this species is popular in saltwater aquariums, and it is caught for fishkeeping near the coasts of West Africa.

In modern works on invasion of alien fish species including $A$. monroviae, researchers generally agree on three most likely pathways of their dispersal beyond the native range: shipping (with ballast water or among the aquatic fouling organisms on the underwater hulls), fishkeeping, and free migrations (Zaitsev, Ozturk, 2001; Luiz-Junior et al., 2004; Boltachev, Karpova, 2014; Batjakas et al., 2015). Findings of the Monrovia Surgeonfish in the Mediterranean have also allowed some researchers to make an assumption about the formation of a tiled rarefied Mediterranean population of this species extending from the Alboran Sea in the west along the North African coast to Israel in the east and an isolated population near Malta (Batjakas et al., 2015; Darmanin et al., 2016; Evans et al., 2017).
In our opinion based on twenty years of ichthyological monitoring in the coastal zone of the Crimean Peninsula, the ballast-water-mediated invasion is possible only for small hydrobionts, primarily, different planktonic plants and animals including ichthyoplankton, or fry and juvenile fish. Besides, the probability of survival of fish in the early stages of ontogenesis after the water discharge through ballast pumps is extremely small. As mentioned above, eggs and larvae of $A$. monroviae are pelagic, but even if they had been introduced into the Black Sea with ballast water, they would certainly have died in winter, whereas the caught specimen had rather large size, which suggests it being at least 3-years-old. This species reaches a maximum length of $45 \mathrm{~cm}$, but usually specimens are 15-30 cm long (FAO, 1981; Golani et al., 2013). This data corresponds to the length of the caught specimen.

Although $A$. monroviae is an aquarium fish species, the release of the described specimen from aquarium is not likely, in our opinion. The analysis of the species composition of Acanthuridae family representatives kept in aquariums and sold in specialized stores for aquarists of Crimea has shown that they all are the Indopacific species and have been bought in the South-East Asia (Indonesia, Thailand, Singapore) or in Sri Lanka. Furthermore, even if this specimen had been intentionally released from aquarium, it would have been shocked by the temperature and salinity drop, but the specimen caught near Balaklava was in excellent

Table 1. Morphometric measurements of the Acanthurus monroviae specimen caught off the southwestern coast of Crimea

\begin{tabular}{lc}
\hline Measurements & Proportion \\
\hline & \% of standard length \\
Maximal body depth & 42.3 \\
Minimal body depth & 9.9 \\
Predorsal distance & 34.2 \\
Postdorsal distance & 14.0 \\
Antepectoral distance & 26.2 \\
Anteventral distance & 35.4 \\
Anteanal distance & 49.8 \\
Pectoventral distance & 14.2 \\
Ventroanal distance & 14.9 \\
Caudal peduncle length & 12.0 \\
Dorsal fin base length & 65.0 \\
Dorsal fin height & 15.3 \\
Anal fin base length & 43.5 \\
Anal fin height & 13.2 \\
Pectoral fin length & 22.5 \\
Pelvic fin length & 19.9 \\
Caudal fin length & 23.9 \\
Head length & 31.0 \\
Head depth through middle of eye & 35.0 \\
Head depth through middle of eye 0.27 & 113.0 \\
Preorbital distance & 61.8 \\
Length of mandible & 14.9 \\
Length of maxilla & 17.0 \\
Porizontal diameter of eye & 20.2 \\
\hline
\end{tabular}



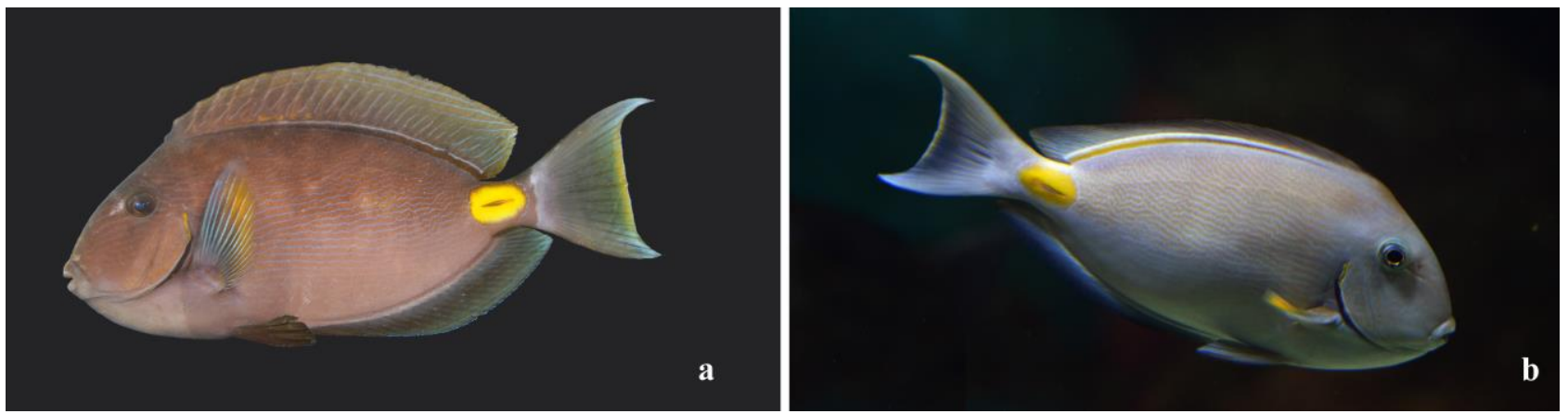

Figure 2. The individual Acanthurus monroviae caught in the Black Sea in a stressful coloration (a) and after adaptation (b).

physiological condition.

In our opinion, most likely is the free penetration of this specimen from the Mediterranean through the Dardanelles and Bosphorus straits to the southwestern coast of Crimea in the summer of 2018. Analysis of the literature data on dispersal of the Monrovia Surgeonfish in the Atlantic Ocean and the seas of the Mediterranean basin shows that this species can migrate over long distances. Very extraordinary is the penetration of this demersal fish to the coast of Brazil which occurred in the open water pelagial of the Atlantic Ocean. The shortest distance between Africa and South America is about $3,000 \mathrm{~km}$, and that between Angola (the southern boundary of the species range in the East Atlantic) and the Laje de Santos Marine State Park (Brazil) is more than $6,000 \mathrm{~km}$. This confirms the high potential of $A$. monroviae in making long migrations. The gradual spread of $A$. monroviae in the Mediterranean from Gibraltar to Israel and from the northern coast of Africa to Malta and the southern Aegean Sea is quite real, and it may have been affected by global warming. Our finding can serve as confirmation of the naturalization of this species in the Mediterranean and gradual increase of its abundance.

The distance from the place of detection of the Surgeonfish in the Aegean Sea to Crimea is about 1,300 $\mathrm{km}$, and the distance from the Anatolian Peninsula of Turkey to the southern coast of Crimea is only about 260 $\mathrm{km}$. In summer, the average surface temperature is around $26^{\circ} \mathrm{C}$ and the salinity is rather stable, $18 \%$. A variety of biotopes are concentrated off the southwestern coast; they are directly related to both the open sea areas and numerous bays different in their morphological and biocenotic features. The coastal area of Balaklava is dominated by rocky and stony landscape biotopes that include steep rock walls falling into the sea depths, large fragments of rocks and big stones densely covered with algae. At an average depth of 8-15 m, they are replaced by biocenoses of sandy bottom. Thus, both hydrological and biocenotic conditions in this area supported the normal existence of the Monrovia Surgeonfish at the time of the specimen capture.

It is worthwhile to note that over the twenty years of ichthyological monitoring in the coastal zone of the southwestern Crimea, 24 fish species have been registered, 12 of which have been found in the Black Sea for the first time (in brackets are the years of finding the species near the coast of the southwestern Crimea): Gobius cruentatus (2002); Millerigobius microcephalus (2009); Pomatoschistus bathi (2002); Tridentiger trigonocephalus (2006); Gobius couchi (2015); Chelon labrosus (1999); Sphyraena pinguis (1999); Micromesistius poutassou (1999); Heniochus acuminatus (2003); Epinephelus caninus (2013); Lagocephalus sceleratus (2014); Acanthurus monroviae (2018). Most of other species first encountered near the Crimean coast are known from their single findings in the Black Sea: Gobius xanthocephalus (2007); Chromogobius quadrivittatus (2015); Zebrus zebrus (2013); Parablennius incognitus (2002); Sparus aurata (1999); Sarpa salpa (1999); Syngnathus acus (2006); Sardinella aurita (1998); Lithognathus mormyrus (2013); Dactylopterus volitans (2013); Dentex dentex (2014); Apletodon dentatus (2014).

At present, we can assume naturalization of 13 fish species in the Black-Sea coastal zone of the Crimean Peninsula: G. cruentatus, M. microcephalus, P. bathi, $T$. trigonocephalus, G. couchi, G. xanthocephalus, C. quadrivittatus, $Z$. zebrus, $P$. incognitus, $S$. aurata, $S$. salpa, L. mormyrus, A. dentatus.

Thus, the increase in diversity of the fish species alien to the ichthyofauna of the Black Sea and the naturalization of some of them observed in approximately the last two decades are probably related to the global climate change, one of the outcomes of which is the water temperature rise. In addition, the findings of a number of species are random, and in this case, we are dealing with such a find. Naturalization of the species in the Black Sea is unlikely, however, the detection of single individuals or small groups of fish may well occur further in the warm season.

\section{Acknowledgements}

We would like to thank S. Sokol and A. Chikunov for giving us a specimen of $A$. monroviae. The work has been done in the framework of the programs "Patterns of Formation and Anthropogenic Transformation of Biodiversity and Bioresources of the Azov-Black Sea Basin and Other Areas of the World Ocean" for the 
period of 2018-2020 within the state assignment AAAAA18-118020890074-2 from A. O. Kovalevsky Institute of Marine Biological Research of Russian Academy of Sciences.

\section{References}

Batjakas, I.E., Kampouris, T., \& Papadas, A. (2015). First record of the African Surgeonfish Acanthurus monroviae (Osteichthyes: Acanthuridae) in the Hellenic Waters. Journal of Aquaculture and Marine Biology, 2(6), 00047. http://dx.doi.org/10.15406/jamb.2015.02.00047

Boltachev, A.R. \& Karpova, E.P. (2014). Faunistic Revision of Alien Fish Species in the Black Sea. Russian Journal of Biological Invasions, 5(4), 225-241. http://doi.org/10.1134/S2075111714040018

Costa, B.H.E. \& Gonçalves E.J. (2013). First occurrence of the Monrovia doctorfish Acanthurus monroviae (Perciformes: Acanthuridae) in European Atlantic waters. Marine Biodiversity Records, 6, e20.

Crespo, J., Rey, J.C. \& Garcia, A. (1987). Primera cita de Acanthurus monroviae Steindachner, 1876 y de Diodon eydouxii Brissout de Barneville, 1846, para la ictiofauna europea. Miscellania Zoologica, 811, 271-275.

Darmanin, S.A., Vella, N. \& Vella, A. (2016). Genetic, morphometric and meristic analyses of first Acanthurus monroviae specimens recorded in Maltese waters (Central Mediterranean). Cybium, 40(4), 338-340.

Evans, J., Tonna, R. \& Schembri, P.J. (2017). A bevy of surgeons: First record of Acanthurus chirurgus (Bloch, 1787) from the central Mediterranean, with notes on other Acanthuridae recorded in the region. Biolnvasions Records, 6(2), 105-109. https://doi.org/10.3391/bir.2017.6.2.03

Fischer, W., Bianci, G. \& Scott, W. B. (1981). FAO Species Identification Sheets for Fishery Purposes. Eastern Central Atlantic. Fishing area 34 and part of 47 . Volume 1. Ottawa, Canada, Department of Fisheries and Oceans Canada, by arrangement with the Food and Agriculture
Organization of the United Nations, pag. var.

Fricke, R., Eschmeyer, W. N. \& Van der Laan, R. (2019). Catalog of fishes: genera, species, references. Retrieved from http://researcharchive.calacademy.org/research/ichthy ology/catalog/fishcatmain.asp.

Golani, D. \& Sonin, O. (1996). The occurrence of the tropical west African marine fishes Acanthurus monroviae (Acanthuridae) and Arius parkii (Ariidae) in the Levant. Aqua - Journal of Ichthyology and Aquatic Biology, 2, 13.

Golani, D., Orsi-Relini, L., Massuti, E., Quignard, J.-P., Dulčić, J. \& Azzurro, E. (2013). CIESM Atlas of Exotic Species in the Mediterranean. Vol.1. Fishes. Retrieved from http://www.ciesm.org/atlas/appendix1.html.

Langeneck, J., Boyer, M., De Cecco, P.G., Luciani, C., Marcelli, M.\& Vacchi, M. (2015). First record of Acanthurus chirurgus (Perciformes: Acanthuridae) in the Mediterranean Sea, with some distributional notes on Mediterranean Acanthuridae. Mediterranean Marine Science, 16(2), 427-431. http://dx.doi.org/10.12681/mms.1239

Luiz-Junior, O.J., Floeter, S.R., Gasparini, J.L., Ferreira, C.E.L. \& Wirtz, P. (2004). The occurrence of Acanthurus monroviae (Perciformes: Acanthuridae) in the southwestern Atlantic, with comments on other eastern Atlantic reef fishes occurring in Brazil. Journal of Fish Biology, 65, 1173-1179. http://dx.doi.org/10.1111/j.1095-8649.2004.00519.x

Nelson, J. S. (2006). Fishes of the world. 4-th edition. New York, USA, John Wiley and Sons Inc., $601 \mathrm{pp}$.

Vasconcelos, P., Carvalho, A. N., Moura, P., Ramos, J., \& Gaspar, M. B. (2018). First record of Acanthurus monroviae (Osteichthyes: Perciformes: Acanthuridae) in southern Portugal, with notes on its recent distributional spread in the northeastern Atlantic and Mediterranean. Marine Biodiversity, 48(3), 1673-1681. http://dx.doi.org/10.1007/s12526-017-0653-z

Zaitsev, Yu. \& Ozturk, B. (2001). Exotic species in the Aegean, Marmara, Black, Azov and Caspian Seas. Istanbul, Turkey, Turkish Marine Research Foundation, 265 pp. 